\title{
Biochemical Variations of Breast Milk Composition Compared with Substitution Formula in Feeding of Preterm of Mothers With or Without Pathologic Pregnancies
}

\begin{abstract}
MARIUS BIRIS*, ADRIAN GLUHOVSCHI*, GEORGETA NODITI, DANIELA IACOB*, MARIUS CRAINA, DORU ANASTASIU, DIANA MARIA ANASTASIU POPOV

Victor Babes University of Medicine and Pharmacy, Department XII, Obstetrics and Gynecology and Neonatology,Bega Clinics, 2 Eftimie Murgu Sq., 300041,Timisoara, Romania

Breast milk is the main source of energy and nutrients for preterm and term newborns. The aim of the study was to determine the biochemical differences between breast milk and substitution formula used in feeding of preterm newborns and differences in composition of breastmilk according to mothers demographic and pregnancy parameters. A group of 54 mothers with pathologic pregnancies of preterm gestational age between 27-37 weeks was studied to determine the biochemical composition of breast milk in the first 7 days of lactation and then to compare it with milk formula substitution. Most of them (42\%) had a diagnosis of chronic hypertension, followed by chronic renal diseases (29\%). Several parameters like gestational age, maternal age, lactation day when sampling milk, type of birth (natural / C-section), origin of mother (rural / urban), gender of the child were analyzed. The biochemical analysis of macronutrients (carbohydrates, lipids, proteins) and energetic value of the collected breast milk was performed by using an indirect method, infrared spectroscopy (mid-infrared transmission spectroscopy) bymeans of an automatic device. Gestational age, mother's age and day of lactation (during the first week post-partum) did not produce a statistically significant difference in the composition of breast milk. There were no statistically significant changes with the type of delivery (cesarean versus natural) and gender of the preterm newborn. Higher lipid, carbohydrates and protein concentration was observed in milk substitution formula than in breast milk. Energetic values of analyzed milk substitution formula showed a statistically significant difference $(p<0.05)$ when compared with breast milk.
\end{abstract}

Keywords: biochemical composition, preterm, breast milk, substitution formula, preterm feeding

Human milk provides the optimal nutrition for term infants. Human milk is also recommended for preterm infants, but does not alone provide optimal nutrition [1]. The World Health Organization recommends that infants should be exclusively breastfed for the first six month of life. The American Academy of Pediatrics also recommends breastfeeding for at least 12 months [2]. It is a large variation in the energy and protein content of human milk (between mothers, over time in a given mother, and between foremilk and hindmilk) [3]. Premature babies have an increased need for protein and calories. Studies to date suggest that the metabolites differing between human milk-fed and formula-fed infants that are most closely associated with shaping the microbiota include sugars and fatty acids [4]. The mostcompelling benefit of human milk feeding is the observed decrease in necrozitis enterocolitis given its high prevalence (5-10\% of all infants with birth weight < 1500 grams), and long-term morbidity [5]. Infant formula is intended as an effective substitute to breast milk and is formulated to mimic the nutritional composition of breastmilk [6].Although production of an identical product to breast milk is not feasible, every effort has been taken to mimic the nutrition profile of human breast milk for normal infant growth and development [7].

The aims of this study were to determine the difference in the composition of breastmilk according to the mother's demographic parameters and the difference in composition of breast milk according to the parameters related to pregnancy: gestational age on lactation, type of birth and sex of newborn premature. Another purpose was to evaluate quantitative differences of macronutrients (carbohydrates, lipids, proteins) and the energetic value of the breast milk, and a standard substitution formula for preterm feeding.

\section{Experimental part}

Material and method

A single-center, observational, retrospective study was conducted during 2013-2014 in the Department of Neonatology Bega in the Emergency County Hospital Pius Brinzeu Timisoara by analyzing a group of 54 patients aged 16-39 years, mothers of preterm gestational age between 27-37 weeks. Biochemical composition of breast milk and composition of formula substitution were compared by analyzing several parameters: gestational age, maternal age, day lactation when sampling milk, type of birth (natural / C-Section), origin of mother (rural / urban), gender of the child. Macronutrients (carbohydrates, lipids, proteins) of milk collected and energetic value were determined. Milk samples were harvested 1-7 days post-partum. The biochemical analysis of breast milk was performed using the indirect method, infrared spectroscopy (mid-infrared transmission spectroscopy) by means of the automatic device. The method consisted in introducing a small amount of collected milk (1-3 ml) into the device to form a thin fluid blade (50 im) which is exposed to radiation MIR (mid-infrared radiation) and the wavelengths were captured. They are specific for certain organic substances in the spectrum of infrared radiation, both qualitatively and quantitatively. Standard filters for components of human milk were used: carbonyl groups ( $C=0$ at $5.7 \mu \mathrm{m})$ specific 
for lipids, amide groups (CONH to $6.5 \mu \mathrm{m}$ ) specific for the protein and hydroxyl groups (-OH $9.6 \mathrm{im}$ ) specific for carbohydrates. The results were expressed in $\mathrm{g} / \mathrm{dl}$. For comparison we used a specific standard formula for premature replacement of the following biochemical composition: protein $2.88 \mathrm{~g} / \mathrm{dL}$, carbohydrates $8.12 \mathrm{~g} / \mathrm{dL}$, fat $4 \mathrm{~g} / \mathrm{dL}$ and energetic value $80 \mathrm{kcal} / \mathrm{dL}$. Data were collected from observation sheets and the results of biochemical tests of breast milk (preterm mothers) were done in the Department of Neonatology Bega. The study received the Ethics Committee and patients gave their consent to the use of their personal data. Data processing and storage were made using the following software: Microsoft Office Excel and Microsoft Office Word. For statistical analysis Student unpaired t-test for categorical variables and ANOVA analysis to analyze continuous variables were used. The reference value of statistical significance was $p=0.05$. The type and degree of correlation were determined using the Pearson correlation coefficient.

\section{Results and discussions}

Out of 54 mothers, 10 cases of women with were with different pathological conditions. Most of them (42\%) had a diagnosis of chronic hypertension, followed by chronic renal diseases (29\%). Of 54 preterm newborns 48 cases $89 \%$ were of moderate prematurity, 5 cases - $9 \%$ of higher prematurity and only one case $(2 \%)$ of extreme prematurity (fig. 1).

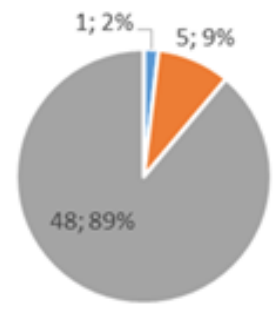

Fig. 1. Preterm distribution according to gestational age
$=<28$ weeks $\quad=28-31$ weeks $=32-27$ weeks

The macronutrients of breast milk was determined according to gestational age. It has been determined that there is a lack of correlation between the amount of carbohydrates, lipids and proteins in the milk and gestational age $(r=+0.167, r=-0.042, r=-0.006$, respectively). The protein concentration shows a peak $(2.2$ $\mathrm{g} / \mathrm{dL}$ ) in cases of extreme prematurity ( $<28$ weeks) followed by a slight downward trend by gestational age with near normal (fig. 2).

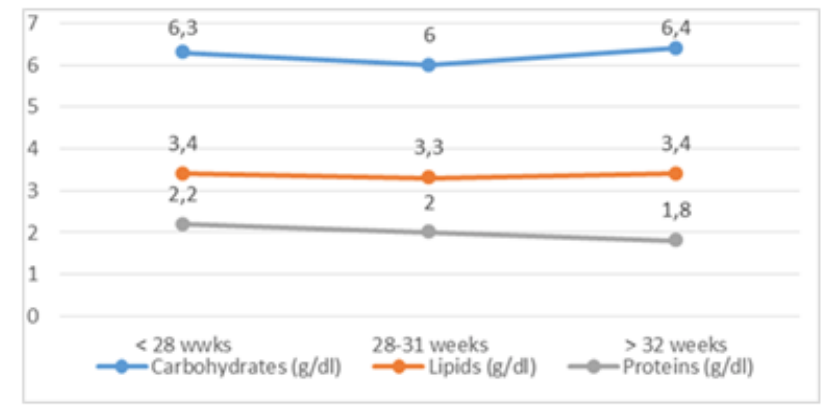

Fig. 2. Macronutrients content of breast milk according to gestational age

Most mothers ( 47 cases - $87 \%$ ) in the study group were aged between 18 and 35 years (the optimal age for conception). The extremes are the three cases under 18, and 4 cases over 35 years of age. Analyzed breast milk samples showed no significant correlation between the amount of carbohydrates, lipids and proteins in the milk and maternal age $(r=-0.283, r=-0.269, r=+0.012$, respectively) (fig. 3).

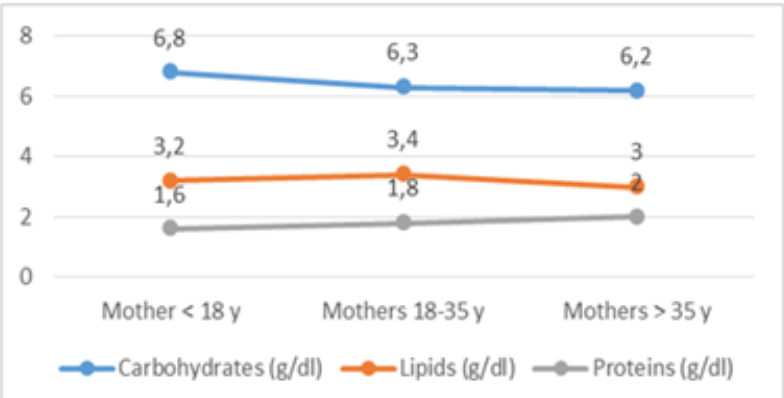

Fig. 3. Macronutrients content of breast milk according to maternal age

Nearly three quarters of the harvested milk (74\%) were collected on days 2-4 of lactation, total harvesting time was during the first seven days of lactation. There was no significant correlation $(r=-0.060, r=+0.181, r=-0.290$, respectively) of the amount of carbohydrates, lipids and proteins in the milk and the day of the first week of postpartum lactation. The concentration of carbohydrates in breast milk samples is relatively constant during the first week post-partum while the protein content has a higher value at the beginning of lactation (colostrum) and easily falls during the first week. Lipids instead shows a slight increase (fig. 4).

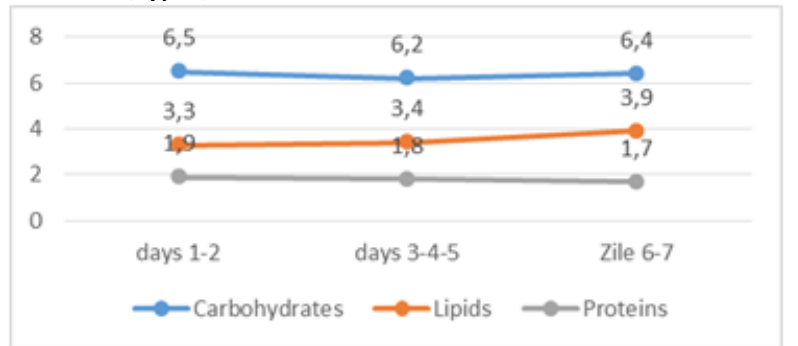

Fig. 4. Macronutrients content of breast milk according to lactation day

Birth by caesarean section predominates ( 37 cases $69 \%)$. There was no statistically significant difference in composition between breast milk macronutrients (carbohydrates, lipids, proteins) depending on the type of delivery $(p=0.48)$. The protein concentration is about $5 \%$ higher $(1.9 \mathrm{~g} / \mathrm{dL}$ versus $1.8 \mathrm{~g} / \mathrm{dL}$ ) in the case of natural birth by comparing with cesarean birth (fig. 5).

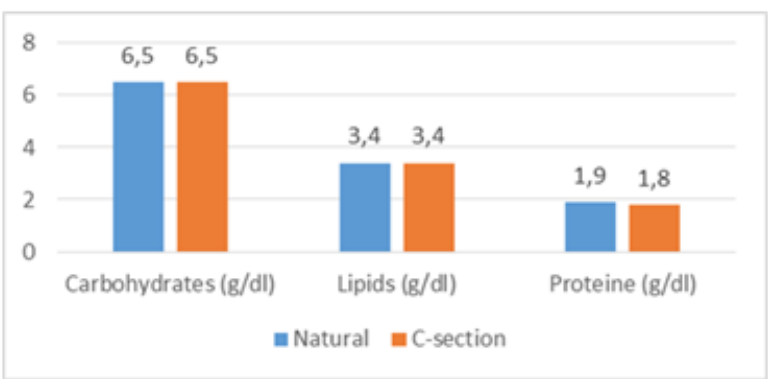

Fig. 5. Macronutrients content of breast milk according to type of preterm delivery

It is a minor difference between the number of mothers from the rural ( 22 cases, $41 \%$ ) and the urban area ( 32 cases, $59 \%)$, one interesting feature being the distribution of extremes in terms of maternal age in rural areas. No statistically significant difference in breast milk composition macronutrients (carbohydrates, lipids, proteins) according to the area of origin of the mother ( $p$ $=0.46$ ) was observed (fig. 6). 


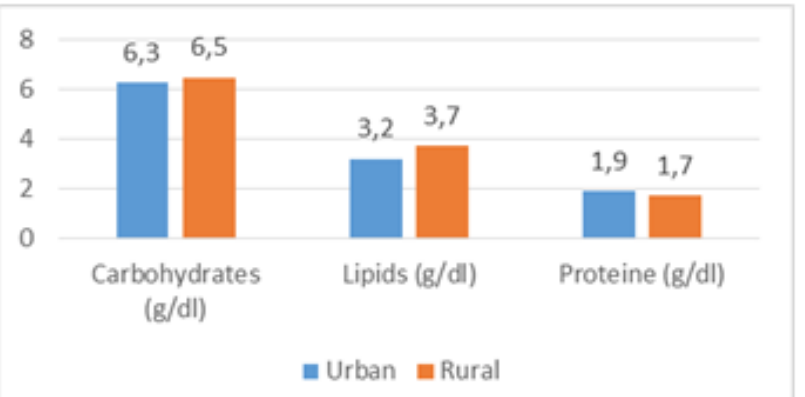

Fig. 6. Macronutrients content of breast milk according to mothers living area

The proportion of the preterm genders are about equal ( $48 \%$ female and $52 \%$ of male). The average values of macronutrients in the two studied homogeneous subgroups are similar, showing only a minor difference in the case of carbohydrates, their concentration being higher by $1.5 \%$ in the case of the male sex (fig. 7).

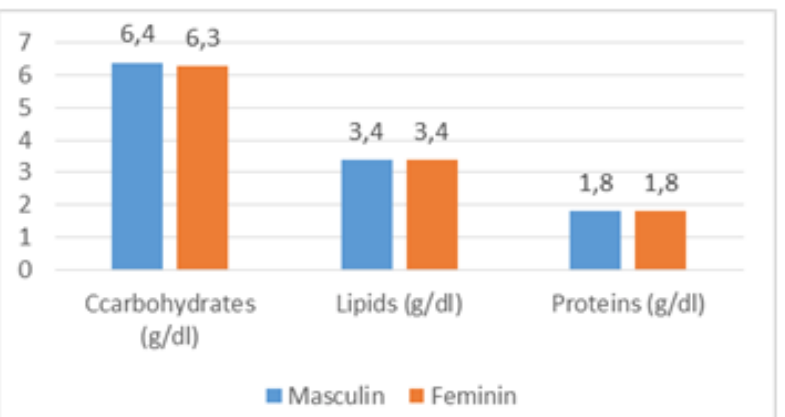

Fig. 7. Macronutrients content of breast milk according to preterm gender

Statistical analysis of the amount of carbohydrates in samples of breast milk and substitution formula showed statistically significant difference $(p<0.05)$. Substitution used formula for comparison showed a difference of $29 \%$ greater $(8.12 \mathrm{~g} / \mathrm{dL}$ versus $6.3 \mathrm{~g} / \mathrm{dL}$ ). Considering the amount of fat in milk samples and substitution formula resulted a statistically significant difference $(p<0.05)$. Substitution used formula for comparison showed higher concentration (17\%). Comparison of the amount of protein in the samples of milk and substitution formula showed no statistically significant difference ( $p>0.05$ ) (fig 8).

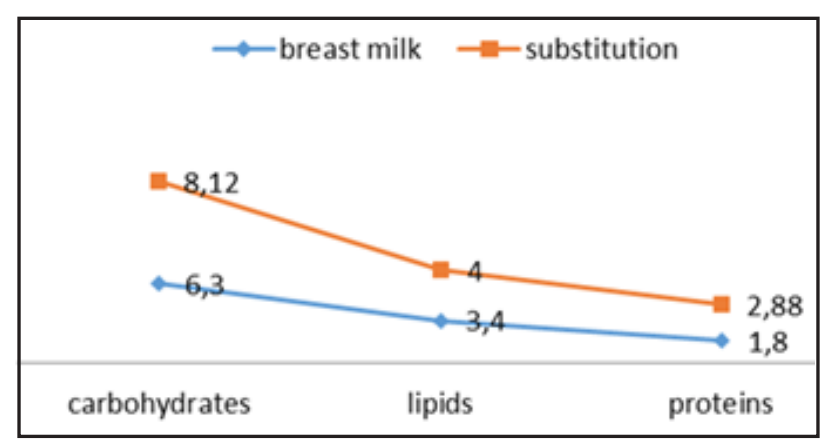

Fig. 8. Macronutrients comparison between breast milk and substitution formula

As a result, comparative statistical analysis of the energetic values of breast milk samples and substitution formula revealed a statistically significant difference $(p$ $<0.05)$. Substitution formula had higher energetic value (19\%).

The composition of human milk is dynamic and variable within a feeding, diurnally, over lactation, between mothers, and with treatment of expressed milk including storage and pasteurization [8]. Understanding variables has a positive impact for feeding infants, especially for those at high-risk and with a very low birth weight. With regard to deliver prematurely, Hsu et al [9] found no significant differences in most components of human milk between the term and preterm mothers. In our study there was no statistically significant difference in composition between milk macronutrients (carbohydrates, lipids, proteins) depending on the type of delivery $(p=0.48)$. In a study Paul et al [10] observed that changes with lactation were more pronounced in preterm than in term milk. Bauer and Gerss [11] reported that carbohydrate, fat, protein, and energy concentrations were significantly higher in preterm than in term human milk. Milk produced by mothers who deliver prematurely is well known to be higher in protein [12]. The protein concentration shows a peak instead $(2.2$ $\mathrm{g} / \mathrm{dL}$ ) in cases of extreme prematurity ( $<28$ weeks) followed by a slight downward trend by gestational age with near normal [12].

Breast milk fat and energy content varies from the start to the end of a feeding, and follows a diurnal pattern in both term [13,14] and preterm milk [14, 15]. Many other factors can influence the composition of human milk (16). The age and residential area of the mother have also been noticed to have an influence, although no definite conclusions have been made to date [16]. In our study, no statistically significant difference in breast milk composition according to rural or urban living area of the mother $(p=0.46)$ was observed.

In a meta-analysis of 41 studies of preterm and term breast milk nutrient content (energy, protein, lactose, oligosaccharides, fat, calcium, and phosphorus) the authors [17] tried to assess the influence of gestational and postnatal age. Meta-analysis summary estimates of breast milk composition per 100 milliliters showed for preterm and for the first week the following values: protein 2.2 $( \pm 0.3-4.1) \mathrm{g}$, lipids 2.6 ( $\pm 0.5-4.7)$, energetic value 60 ( \pm 45 75). For term newborns the estimated values were: protein $1.8(0.4-3.2)$, lipids $2.2(0.7-3.7)$, energetic value 60 ( \pm 44 77). Although breast milk is highly variable between individuals, postnatal age and gestational stage (preterm versus term) were found to be important predictors of breast milk content [17].

In our study, the average values of breast milk composition macronutrients are almost identical on both sexes of the premature newborn, resulting no significant correlation $(p=0.49)$. A study dealing with this topic for infants term results are discordant with our current study, resulting in a higher concentration carbohydrate in milk of mothers with feminine gender newborn [18].

Similar values are obtained if the concentration of carbohydrate and lipid regardless of the type of delivery (natural or cesarean). The protein concentration is about $5 \%$ higher $(1.9 \mathrm{~g} / \mathrm{dL}$ versus $1.8 \mathrm{~g} / \mathrm{dL})$ in the case of natural birth by comparing with cesarean birth. These results support the literature, natural birth through labor pains and uterine contractions associated with hormonal stronger impact on milk production and on protein concentration of colostrum [19].

The average concentration of carbohydrate in the milk of mothers of preterm is $7.34 \mathrm{~g} / \mathrm{dL}$ according to a metaanalysis published in the British J ournal of Nutrition in 2016 [20]. Comparing this average with the average concentration of carbohydrate in the current study breast milk a difference of $16 \%(7.34 \mathrm{~g} / \mathrm{dL}$ versus $6.3 \mathrm{~g} / \mathrm{dL}$ ) was noted. The average value of the concentration of milk lipid of mothers of preterm $(3.46 \mathrm{~g} / \mathrm{dL})$ from a meta-analysis [20] and from the current study media $(3.4 \mathrm{~g} / \mathrm{dL}$ ) is similar. The concentration of breast milk proteins from our study 
was $41 \%$ higher ( $1.8 \mathrm{~g} / \mathrm{dL}$ ) then the value reported in meta-analysis $(1.27 \mathrm{~g} / \mathrm{dL})$ [20].

In our study, statistical comparison of the amount of carbohydrates and lipids in samples of breast milk and substitution formula showed statistically significant difference $(p<0.05)$. The lipid values in the chosen substitution formula were $17 \%$ higher. Statistical comparison of the amount of protein in the samples of milk and substitution formula showed no statistically significant difference $(p>0.05)$. Substitution used formula for comparison showed a difference of $29 \%$ greater ( 8.12 $\mathrm{g} / \mathrm{dL}$ versus $6.3 \mathrm{~g} / \mathrm{dL}$ ) than the breast milk. On the other hand the protein concentration in substitution formulation is $60 \%$ higher than the average of the current study. Substitution formula had higher energetic value (19\%).

In conclusion, gestational age, mother's age and day of lactation (during the first weeks post-partum) did not showed a statistically significant difference in the composition of breast milk, as well as the type of delivery (cesarean versus natural) and gender of the preterm newborn. Higher lipid, carbohydrates and protein concentration was observed in milk formula than in breast milk.

\section{References}

1. MARK A. UNDERWOOD. Human milk for the premature infant. Pediatr Clin North Am. 2013; 60(1): p: 189-207, doi: [10.1016/ j.pcl.2012.09.008] PMCID: PMC3508468NIHMSID: NIHMS411001PMID: 23178065).

2. EIDELMAN, A.I.; SCHANLER, R.J.; JOHNSTON, M.; LANDERS, S.; NOBLE, L.; SZUCS, K.; VIEHMANN, L. Breastfeeding and the use of human milk. Pediatrics 2012, 129, p: 827-841.

3. WEBER A, LOUI A, JOCHUM F, BUHRER C, OBLADEN M. Breast milk from mothers of very low birth weight infants: variability in fat and protein content. Acta Paediatr. 2001 Jul; vol 90(7), p: 772-775. [PubMed].

4. POROYKO V, MOROWITZ M, BELL T, et al. Diet creates metabolic niches in the immature gut that shape microbial communities. Nutr Hosp. 2011 Nov-Dec; vol 26(6), p:1283-1295. [PubMed]

5. HINTZ SR1, KENDRICK DE, STOLL BJ, VOHR BR, FANAROFF AA, DONOVAN EF, POOLE WK, BLAKELY ML, WRIGHT L, HIGGINS R. Neurodevelopmental and growth outcomes of extremely low birth weight infants after necrotizing enterocolitis. Pediatrics. $2005 \mathrm{Mar}$; vol 115(3) p: 696-703. [PubMed].

6. LONNERDAL, B. Preclinical assessment of infant formula. Am. Nutr. Metab. 2012, vol 60, p: 196-199. [Google Scholar] [CrossRef] [PubMed]

7. CAMILIA R. MARTIN , PEI-RA LING AND GEORGE L. BLACKBURN. Review of Infant Feeding: Key Features of Breast Milk and Infant Formula Nutrients 2016, vol 8 (5) p: 1-11; doi:10.3390/nu8050279

8. MEI-YUNG CHUNG. Factors Affecting Human Milk Composition. Pediatrics and Neonatology December 2014 Volume 55, Issue 6, p: 421-422.

9. HSU, Y.C., CHEN, C.H., LIN, M.C., TSAI, C.R., LIANG, J.T., AND WANG, T.M. Changes in preterm breast milk nutrient content in the first month. Pediatr Neonatol. 2014; vol 55, p: 449-454.
10. PAUL, V.K., SINGH, M., SRIVASTAVA, L.M., ARORA, N.K., AND DEORARI, A.K. Macronutrient and energy content of breast milk of mothers delivering prematurely. Indian J Pediatr. 1997; vol 64, p: 379382.

11. BAUER, J. AND GERSS, J. Longitudinal analysis of macronutrients and minerals in human milk produced by mothers of preterm infants. Clin Nutr. 2011; vol 30 p: 215-220.

12. AGOSTONI C, BUONOCORE G, CARNIELLI VP, DE CURTIS M, DARMAUN D, DECSI T, DOMELLOF M, EMBLETON ND, FUSCH C, GENZEL-BOROVICZENY O, GOULET O, KALHAN SC, KOLACEK S, KOLETZKO B, LAPILLONNE A, MIHATSCH W, MORENO L, NEU J, POINDEXTER B, PUNTIS J, PUTET G, RIGO J, RISKIN A, SALLE B, SAUER P, SHAMIR R, SZAJEWSKA H, THUREEN P, TURCK D, VAN GOUDOEVER JB, ZIEGLER EE. ESPGHAN Committee on N. Enteral nutrient supply for preterm infants: commentary from the European Society of Paediatric Gastroenterology, Hepatology and Nutrition Committee on Nutrition.J Pediatric Gastroenterol Nutr. 2010; vol 50(1), p:85-91. doi: 10.1097/MPG.0b013e3181adaee0. [PubMed] [CrossRef]. 13. KHAN S, HEPWORTH AR, PRIME DK, LAI CT, TRENGOVE NJ, HARTMANN PE. Variation in fat, lactose, and protein composition in breast milk over 24 hours: associations with infant feeding patterns. J Hum Lact. 2013; vol 29(1), p: 81-89. doi: 10.1177/0890334412448841. [PubMed] [CrossRef]

14. KOCISZEWSKA-NAJ MAN B, BOREK-DZIECIOL B, SZPOTANSKASIKORSKA M, WILKOSE, PIETRZAK B, WIELGOSM. The creamatocrit, fat and energy concentration in human milk produced by mothers of preterm and term infants. J Matern Fetal Neonatal Med. 2012; vol 25(9), p:1599-1602. doi: 10.3109/14767058.2011.648239. [PubMed] [CrossRef]

15. LUBETZKY R, LITTNER Y, MIMOUNI FB, DOLLBERG S, MANDEL D. Circadian variations in fat content of expressed breast milk from mothers of preterm infants. I Am Coll Nutr. 2006; vol 25(2), p:151-154. doi: 10.1080/07315724.2006.10719526. [PubMed] [CrossRef].

16. BACHOUR, P., YAFAWI, R., JABER, F., CHOUEIRI, E., AND ABDELRAZZAK, Z. Effects of smoking, mother's age, body mass index, and parity number on lipid, protein, and secretory immunoglobulin a concentrations of human milk. Breastfeed Med. 2012; vol 7, p: 179188.

17. DOMINICA A GIDREWICZ AND TANIS R FENTON. A systematic review and meta-analysis of the nutrient content of preterm and term breast milk BMC Pediatr. 2014; vol 14, p: 1-14, 216.PMCID: PMC4236651PMID: 25174435.

18. WON-HO HAHN, JOON-HWAN SONG, SEUNGHYUN SONG. Do gender and birth height of infant affect calorie of human milk? An association study between human milk macronutrient and various birth factors, , The Journal of Maternal-Fetal \& Neonatal Medicine, 2017. Volume 30, 2017 - Issue 13, p: 1608-1612, doi.org/10.1080/ 14767058.2016.1219989.

19. EVRIM ALYAMAC DIZDAR, FATMA NUR SARI, HALIL DEGIRMENCIOGLU, FUAT EMRE CANPOLAT, SERIFE SUNA OGUZ, NURDAN UGAS, UGUR DILMEN. Effect of mode of delivery on macronutrient content of breast milk, The J ournal of Maternal-Fetal \& Neonatal Medicine, 2014 Volume 27, 2014 - Issue 11, p: 1099-1102, https://doi.org/10.3109/14767058.2013.850486.

20. CATHERINE BOYCE, MISTRAL WATSON, GRACE LAZIDIS, SARAH REEVE. Preterm human milk composition: a systematic literature review, 2016. British J ournal of Nutrition Volume 116, Issue 628 , 2016, p: 1033-1045).

Manuscript received: 7.07 .2018 